\title{
Assessment of the Physicochemical and Heavy Metal Concentration from Effluents of Paint Industry in Addis Ababa, Ethiopia
}

\section{Dessalew Berihun ${ }^{1 *}$ and Yonas Solomon}

${ }^{1}$ Department of Environmental Management, Kotebe Metropolitan University, Addis Ababa, Ethiopia

${ }^{2}$ Department of Environmental Health Sciences and Technology, Jimma University, Jimma, Ethiopia

\begin{abstract}
Paint industry is one of the industries that cause the water pollution by generating Wastewater primarily due to cleaning operations of mixers, reactors, blenders, packing machines and floors. The present research work deals with the study of some of the important physico-chemical and heavy metal parameters of paint industrial waste water effluents which was aimed at the analysis of the untreated effluents from six paint factories in Addis Ababa and the surrounding area. Analysis physico-chemical and heavy metal parameters of selected paint factories samples in Kadisco (KA), Zemilli (ZE), Rainbow (RA), Gastor solar (GA), Nifas silk (NI) and Modern building industry (MBI) were performed to investigate the concentration of status of the parameter. In this study, like; physico-chemical and heavy metal parameters $\mathrm{pH}, \mathrm{EC}$, TDS, TSS, COD, $\mathrm{Cd}, \mathrm{Cr}, \mathrm{Pb}$, and $\mathrm{Zn}$ of the nine wastewater samples were analyzed using, Dana multi-meter, Jenway Model 4510 Conductivity/Temp Meter (451 001), Gravimetric, Volumetric, Colorimetric, flame emission photometry, and Atomic Absorption spectrometry (AAS)analyses methods. In the investigation some parameters were found to be above the limit set by ES and WHO. Values obtained for pH at KA, ZE, RA, GA, NI and MBI were 7.95, 8.34, 7.68, 10.95, 7.85 and 8.41; E.C:-55.1, 3.149, 675.9, 2.417, 549.6 and 3.169. TSS:-63, 205, 80, 55, 1980 and $418 \mathrm{mg} / \mathrm{l}$ and TDS:-501, 1, 2.849, 615.2, 2.207 and 2.883mg/l and COD:- 100, 340, 270, 140, 2190 and $2670 \mathrm{mg} / \mathrm{l}$. On the other hand, results obtained from Atomic Absorption Spectrophotometer analysis (AAS) showed the average metal levels as $\mathrm{Cd}^{2+}, \mathrm{Cr} P b 2$ and $\mathrm{Zn}^{2+}$ were all sites above the permissible limit set by ES and WHO (detected $\mathrm{mg} / \mathrm{L}$ ).
\end{abstract}

Keywords: Parameters; Wastewater; Pollution; Effluent wastewater; Paint industry; Influent wastewater

\section{Introduction}

Industrialization is seen as a motor behind many of the processes usually termed "social transformation" and "modernization". Paint industry is one of the industries that cause the water pollution. Wastewater is generated primarily due to cleaning operations of mixers, reactors, blenders, packing machines and floors. Heavy metals have been found to be highly toxic especially when their natural concentrations are exceeded. At normal concentration, they promote the functions of the enzymes but could lead to a lot of adverse metabolic reaction when their concentration rises beyond tolerance limit. The untreated effluents contain a lot of pollutants that are harmful to human beings when they exceed the permissible limits. The Zemilli Paint Factory in Ethiopia produces maximum of 36,000 liters of paint per day and as a result it generates about 500 liters of liquid waste on average per day. This massive quantity of untreated effluent is disposed to the river side and cause considerable load on the water courses leading to widespread damage to aquatic life and to the environment. The problem is more severe in Addis Ababa, where most (More than 40\% of large and medium scale manufacturing industries are located. Addis Ababa, like most developing cities, lacks the infrastructure, financial resources, and institutional capacity necessary to effectively manage industrial wastes and adequately control industrial pollution [1]. Paint manufacturing sector in Addis Ababa localized in different part of the sub city, most of them were concentrated in the residential and commercial area such as Nifas silk lafto sub city and Akaki Kality sub city. However, some of them are found in regional state. They have no proper waste discharging mechanism and no modern treatment plant which can handle their effluents waste accordingly.

\section{Materials and Methods}

\section{Study area}

This study was employ on the city of Addis Ababa. Addis Ababa $\left(9^{\circ} \mathrm{N}, 38.5^{\circ} \mathrm{E}\right)$ is the capital city of the Federal Democratic Republic of Ethiopia situated in the high plateaus of central Ethiopia in the NorthSouth oriented mountain system neighboring the rift- valley. The city, established in 1986, has experienced several planning changes that have influenced its physical and social growth. Its population is 2.7 million (2007 estimate); and about $3.9 \%$ of the total population of Ethiopia. It also represents about $28 \%$ of the urban population of the country with a life expectancy of 48 years. The city has experienced rapid population growth with an annual rate of 3.8 percent per year. It has a total land area of 54,000 hectares, situated 1500-3100 meter above sea level, with an aggregate population density of $4,847.9$ persons per square kilometer. For administrational purposes the city is divided into $10 \mathrm{sub}$ cities. It is also home to the African Union, the Economic Commission for Africa and other international organizations". The city makes a significant role in the economic, social and political development of the country. A preliminary visit in the study area was undertaken using vehicles in order to select six sampling sites. The selection of these sampling sites was based on the location (residential and commercial) by considering the relative amount of wastewater discharging paint effluent of Pollutant to the nearby environment and accessibility of the sites to investigation. Primary data was obtained from the six selected sites. Kadisco Paint, Zemilli Paint Nifas Silk Paint, Rainbow Paint, Gast

*Corresponding author: Berihun D, Department of Environmental Management Kotebe Metropolitan University, Addis Ababa, Ethiopia, Tel: +234 (0) 803672 3009; E-mail: nwankwoala_ho@yahoo.com

Received October 07, 2017; Accepted October 22, 2017; Published October 29, 2017

Citation: Berihun D, Solomon Y (2017) Assessment of the Physicochemical and Heavy Metal Concentration from Effluents of Paint Industry in Addis Ababa Ethiopia. Int J Waste Resour 7: 306. doi: 10.4172/2252-5211.1000306

Copyright: $\odot 2017$ Berihun D, et al. This is an open-access article distributed under the terms of the Creative Commons Attribution License, which permits unrestricted use, distribution, and reproduction in any medium, provided the original author and source are credited. 
solar and modern building industry factory wastewater sampling is made on site by applying stratified random sampling technique. The wastewater sample collected is analyzed for the presence and amount of physicochemical and heavy metal concentration at Addis Ababa University, faculty of science environmental laboratory and chemistry department laboratory.

\section{Sample collection}

The paint wastewater effluent samples were collected randomly in April from 1- 4 days in the Morning and afternoon session from six different paint factory. Polythene bottles of $2.5 \mathrm{~L}$ and $2 \mathrm{~L}$ were used to collect the garb water samples. The bottles thoroughly cleaned with hydrochloric acids, washed with tape water to render free acids, washed with distill water twice, again rinsed with the water sample to be collected and filled up the bottle with the sample leaving only a small air gap at the top. The sample bottles were Stoppard. Each of the samples Wastewater was collected at the output point of each of the six selected sites. Care was taken not to introduce errors during sampling and storage where contamination resulting from improperly cleaned sampling devices and sample containers. Loss of metals by absorption or precipitation in sample containers was avoided by acidifying the sample properly using $\mathrm{HNO}_{3}$ and chromic acids. The equipments used to withdraw waste water sample from equalization tank were selected to keep physical or chemical alterations of the sample to a minimum and to preserve sample Integrity. Devices used for collecting waste water samples both for physicochemical and metals analysis were made of plastic.

Sample Preservation is made by adding $1.5 \mathrm{ml}$ of concentrated $\mathrm{HNO}_{3}$ per liter of sample as stated in environmental sampling and analysis for metals. Sampling Equipment's were cleaned before sampling and at the end of sampling, sampling equipment labeled referring to the Sampling point and date of sampling. Distill water is used for rinsing. In waste water sampling; care was made to reduce changes in the chemistry of the samples. To sustain the natural chemistry of the samples, preservation methods such as $\mathrm{pH}$ control, refrigeration and protecting from light was performed.

The entire samples container were appropriately labeled, identified and distinguished from each other for further separation in the laboratory. Besides, care had been taken when packing samples. Then after, the labeled Sample waste water was transported for four consecutive days to Addis Ababa university environmental science and chemistry department laboratory so that appropriate sample receipt, storage, analysis and arrangements were provided. All the apparatus (hot plate, conical (Erlenmeyer) flasks, $125 \mathrm{ml}$ or Griffin beakers 150 $\mathrm{ml}$; volumetric flasks, $100 \mathrm{~m}$ land other pipettes were acid-washed and rinsed with double distilled water thoroughly. the pipettes and burette were rinsed with solution before final use. the chemicals and reagent were used for analysis were of analytical reagent grade. the procedure for calculating the different parameters were conducted in the laboratory.

\section{Physicochemical parameters}

Physico chemical parameter study is very important to get exact idea about the quality of wastewater and we can compare results of different physico chemical parameter values with standard values.

The techniques and the methods follow for collection, preservation, analysis and interpretation based on America public health association standard methods for estimation wastewater. The samples were collected for analysis of pH, Conductivity (E.C), and Total Dissolved Solid (TDS), Total Suspended Solids (TSS), and Chemical Oxygen Demand (COD) and conducted at Addis Ababa University of Environmental Science laboratory (AAUESL). The $\mathrm{pH}$ of the sample was determined by the same Direct Reading Engineering Method (DREM) using the same Dana multi-meter. The probe of the meter was dipped into beaker of $50 \mathrm{ml}$ effluent sample, and the $\mathrm{pH}$ mode called up. The value displayed was taken as the true $\mathrm{pH}$ value. Electrical conductivity is widely used to indicate the total ionized constituents of water. It is directly related to the sum of the cations (or anions), as determined chemically and is closely correlated, in general, with the total salt concentration. Electrical conductivity is a rapid and reasonably precise determination and values are always expressed at a standard temperature of $25^{\circ} \mathrm{C}$ to enable comparison of readings taken under varying climatic conditions. It should be noted that the electrical conductivity of solutions increases approximately 2 percent per ${ }^{\circ} \mathrm{C}$ increase in temperature. The unit of electrical conductivity is deciSiemen per meter $(\mathrm{dS} / \mathrm{m})$ ormg/l $\sim 640 \times$ $\mathrm{EC}$ in $\mathrm{dS} / \mathrm{m}$. Conductivity was used to measure Electrical Conductivity using Jenway model 4510 conductivity/temp meter (451 001). The probe of the meter was dipped into beaker of $50 \mathrm{ml}$ effluent sample, and the E.C mode called up. The value displayed was taken as the true E.C value. The TDS was determined by the Direct Reading Engineering Method (DREM) using DANA multi-meter, pre-calibrated according to the manufacturer's instruction. A $50 \mathrm{ml}$ volume of the paint effluent sample was introduced into $100 \mathrm{ml}$ glass beaker. The probe of the meter was dipped into the beaker, and the TDS mode activated by pressing gently on the meter's soft touch button. The value displayed at the LCD panel of the meter was allowed to stabilize and recorded as the true value of the reading.

The Total Suspended Solid was determined by the gravimetric method. Porcelain crucible was dried in an oven at 100 oc to obtain a known constant weight WI. A $50 \mathrm{ml}$ volume of the paint effluent sample was introduced into the crucible and the crucible heated in an oven at $100^{\circ} \mathrm{C}$ until the effluent sample vaporized. It was cooled in desiccators and reweighed to obtain $\mathrm{W} 2$.

The Total Suspended Solid was calculated using the equation: -

$$
\text { Total suspended solid TSS }=\underline{\mathrm{W} 2-\mathrm{W} 1} \times 100
$$

$$
50 \mathrm{ml}
$$

The chemical Oxygen Demand is the measurement of the amount of oxygen in water and wastewater consumed for chemical oxidation of pollutant. COD determine the quantity of oxygen required to oxidize the organic matter in water or waste water sample, under specific condition of oxidizing agent, temperature and time.

Take $2.5 \mathrm{ml}$ of wastewater sample and take $2.5 \mathrm{ml}$ of distill water in another tube and add $1.5 \mathrm{ml}$ potassium dichromate to both tubes and form yellow color. Carefully add $3.5 \mathrm{ml}$ sulfuric acids reagent to both tubes and tightly close the tubes and kept on the COD digester at $150^{\circ} \mathrm{C}$ for 2 hours. After cooling to room temperature transfer to the conical flask. Fill the burette with freshly prepared ferrous ammonium sulphate and add a drop ferroin indicator to the conical flask, form green color and titrate the content against ammonium sulphate continue until the color change into reddish brown and calculate the COD concentration.

\section{Chemical Oxygen Demand $=\underline{A-B} \times \mathrm{N} \times 8 \times 1000$}

\section{Volume of the sample}

Concentration of heavy metals such as $(\mathrm{Cd}, \mathrm{Pb}, \mathrm{Zn}$, and $\mathrm{Cr})$ was determined using Flame Atomic Absorption Spectrophotometer (AAS). All instrumental measurements were performed using the respective hallow cathode lamps of target metals at recommended wavelengths 
and other operating conditions. An appropriate digestion method was optimized for the analyses of heavy metals $(\mathrm{Cd}, \mathrm{Cr}, \mathrm{Pb}$ and $\mathrm{Zn})$ for paint wastewater sample. During the optimization process, digestion procedure that employs $\mathrm{HNO}_{3}$ and chromic was selected from literature and assessed [2].

\section{Results and Discussion}

$\mathrm{pH}$ : The extreme $\mathrm{pH}$ of effluent is generally not acceptable, as lower $\mathrm{pH}$ cause problems to survival of aquatic life. The range of the measured $\mathrm{pH}$ values were 7.68 (RB), 7.85 (NS), 7.95 (KA), 8.41 (MBI), 8.34 (ZE) and 10.95 (GS), thereby indicating the alkaline nature of the paint effluent. At high $\mathrm{pH}$ most of the metals become insoluble and accumulate in the sludge and sediments. The toxicity of heavy metals also gets enhanced at particular $\mathrm{pH}$. The entire $\mathrm{pH}$ values lie within the guideline limit except site GS which is higher than the WHO permissible range of 6-9. Whereas according to Ethiopian standards and WHO the GS show above the guideline limit (Figure 1). This is due to unable to do the minimum neutralization process with aluminum sulfate $\left(\mathrm{Al}_{2} \mathrm{SO}_{4}\right)$. Therefore, except GS, this wastewater would have no adverse impact on fauna and flora of receiving environment. The study stated that stated the range of the measured $\mathrm{pH}$ values was $9.56-10.38$, which is higher than the WHO permissible range of $6-9$ (Figure 1) [3-10].

\section{Electrical conductivity}

The electric conductivity of water is a measure of the ability of a solution to conduct an electric current; this ability depends upon the presence of ions, their total concentration, mobility and temperature of water. The conductivity of the water is one of the important parameter used to determine the suitability of water for irrigation. It is useful indicator for salinity or total salt content of waste water. In present study electrical Conductivity showed significant correlation with ten parameters such as temperature, $\mathrm{pH}$ value, alkalinity, total hardness, calcium, total solids, total dissolved solids, chemical oxygen demand, and chloride and iron concentration of water [3]. The values of the study ranged of untreated paint effluent ranges between $35,264(\mu \mathrm{S} / \mathrm{m}) \mathrm{KA})$, 154, $688(\mu \mathrm{S} / \mathrm{m})(\mathrm{GS}), 201,536(\mu \mathrm{S} / \mathrm{m})(\mathrm{ZE}), 202,816(\mu \mathrm{S} / \mathrm{m})(\mathrm{MBI})$, $351,744(\mu \mathrm{S} / \mathrm{m})(\mathrm{NS})$, and $432,576(\mu \mathrm{S} / \mathrm{m})(\mathrm{RB})$ and the values of E.C are within the guideline limit at site KA, GS, ZE, MBI whereas in site NS and RB were higher than the permissible limits $(400 \times 640=256,000$ $(\mu \mathrm{S} / \mathrm{m})$ [11-17].

\section{Total suspended solid (TSS)}

TSS level of untreated paint effluent ranges from $55 \mathrm{mg} / \mathrm{l}(\mathrm{GS}), 63$ $\mathrm{mg} / \mathrm{l}(\mathrm{KA}), 80 \mathrm{mg} / \mathrm{l}$ (RB), $205 \mathrm{mg} / \mathrm{l}$ (ZE), $418 \mathrm{mg} / \mathrm{l}$ (MBI) to $1980 \mathrm{mg} / \mathrm{l}$ (NS) indicating that the values of TSS is higher than the permissible limit (30-35 mg/l) prescribed by WHO. This may be due to presence of large amounts of salts in the effluent (Figure 2).

\section{Total dissolved solid (TDS)}

Total dissolved solid is the measure of total inorganic salts and other substances that are dissolved in water. The effluents with high TDS value may cause salinity problem if discharged to irrigation water. In this study Experimental data showed that TDS of untreated paint effluent ranges between $501.1 \mathrm{mg} / \mathrm{l}(\mathrm{KA}), 284.9 \mathrm{mg} / \mathrm{l}(\mathrm{ZE}), 475.7 \mathrm{mg} / \mathrm{l}$ (NS), $615.2 \mathrm{mg} / \mathrm{l}(\mathrm{RB}), 2,207 \mathrm{mg} / \mathrm{l}(\mathrm{GS})$ and $2,883 \mathrm{mg} / \mathrm{l}(\mathrm{MBI})$ and all the values of TDS was fall within permissible limits $(3000 \mathrm{mg} / \mathrm{l}$ as per ES). However, RB, GS, MBI beyond the WHO limit. Similar studies stated that TDS concentration was $224 \mathrm{mg} / \mathrm{L}$, which complied with WHO Permissible limit of $500 \mathrm{mg} / \mathrm{l}$ for discharge into potable waters (Figure 3).

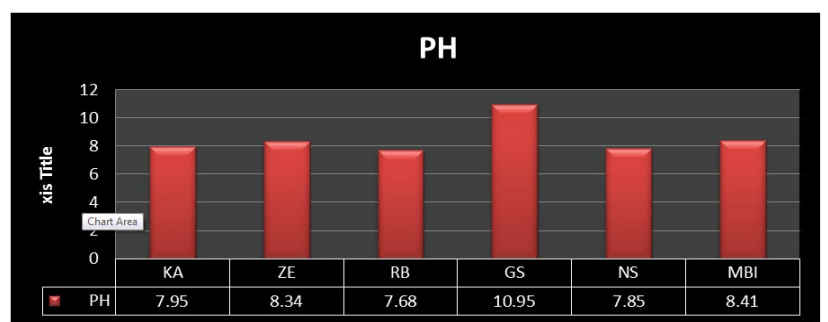

Figure 1: Analysis of $\mathrm{pH}$

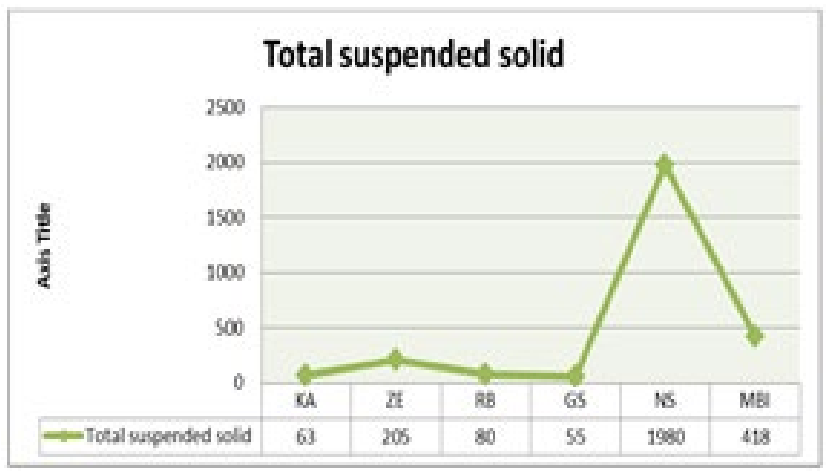

Figure 2: Analysis of total suspended solid (TSS).

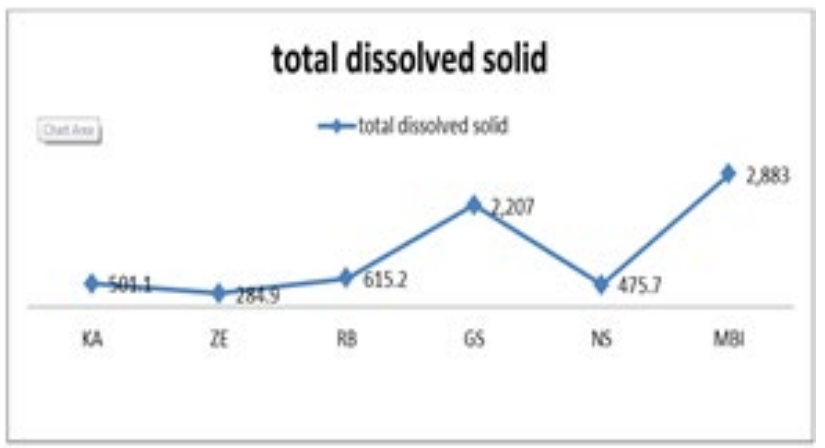

Figure 3: Analysis of total dissolved solids (TDS).

Chemical oxygen demand (COD): According to the result obtained, the mean COD of untreated paint effluent ranges between $100 \mathrm{mg} /$ $\mathrm{l}(\mathrm{KA}), 140 \mathrm{mg} / \mathrm{l}(\mathrm{GS}), 270 \mathrm{mg} / \mathrm{l}(\mathrm{RB}), 340 \mathrm{mg} / \mathrm{l}(\mathrm{ZE}), 2190 \mathrm{mg} / \mathrm{l}(\mathrm{NS})$ and $2670 \mathrm{mg} / \mathrm{l}(\mathrm{MBI})$ and the values of the COD of untreated sample in site $\mathrm{RB}, \mathrm{ZE}$, NS AND MBI are beyond the permissible limit set by ES ( 250 $\mathrm{mg} / \mathrm{l})$ and also GS beyond the permissible limit of WHO $(120 \mathrm{mg} / \mathrm{l})$. Showing that the effluent contained mostly biologically degradable substances. This may be due to the presence of large amount of toxic substances present in the effluent, however, site is KA within as per ES and WHO (Figure 4).

The experimental collective data on physicochemical properties of waste water samples collected from different paint factory site of Addis Ababa are represented in Table 1 (KA: Kadisco paint factory, ZE: Zemilli paint factory RB: Rainbow paint factory. GS: Gastor solar paint factory; NS: Nifas silk paint factory; MBI: Modern building industry) [18-24].

Cadmium (Cd): According to the result showed in Table 2 the mean $\mathrm{Cd}$ concentration in paint wastewater samples was found to be detected 


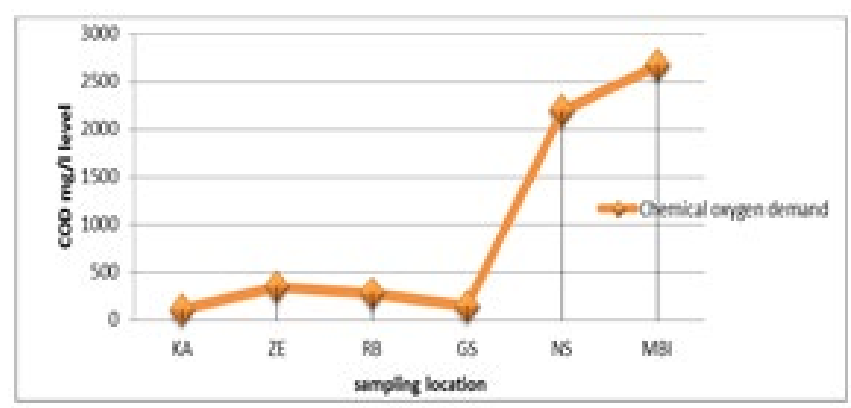

Figure 4: Analysis of chemical oxygen demand.

\begin{tabular}{|c|c|c|c|c|c|}
\hline Location(sites) & $\mathbf{C O D ( m g / l )}$ & $\mathbf{E . C}(\boldsymbol{\mu S} / \mathbf{m})$ & $\mathbf{p H}$ & $\mathbf{T S S}(\mathbf{m g} / \mathbf{l})$ & $\mathbf{T D S}(\mathbf{m g} / \mathbf{l})$ \\
\hline $\begin{array}{c}\text { Kadisco paint } \\
\text { factory }\end{array}$ & 100 & 35,264 & 7.95 & 63 & 501.1 \\
\hline $\begin{array}{c}\text { Zemilli paint } \\
\text { factory }\end{array}$ & 340 & 201536 & 8.34 & 205 & 284.9 \\
\hline $\begin{array}{c}\text { Rainbow paint } \\
\text { factory }\end{array}$ & 270 & $4,32,576$ & 7.68 & 80 & 615.2 \\
\hline $\begin{array}{c}\text { Gastor solar } \\
\text { paint factory }\end{array}$ & 140 & $1,54,688$ & 10.95 & 55 & 2,207 \\
\hline $\begin{array}{c}\text { Nifas silk paint } \\
\text { factory }\end{array}$ & 2190 & 351744 & 7.85 & 1980 & 475.7 \\
\hline $\begin{array}{c}\text { MBI paint } \\
\text { factory }\end{array}$ & 2670 & 202816 & 8.41 & 418 & 2,883 \\
\hline
\end{tabular}

Table 1: Result of physicochemical parameters in paint wastewater sample.

\begin{tabular}{|c|c|c|c|c|}
\hline Location & Mean(Cd) & Mean(Pb) & Mean(Cr) & Mean(Zn) \\
\hline $\begin{array}{c}\text { Kadisco } \\
\text { paint(KA) }\end{array}$ & 0.8134 & 0.7861 & 0.46 & 0.5155 \\
\hline $\begin{array}{c}\text { Zemilli paint } \\
\text { (ZE) }\end{array}$ & 0.7015 & 0.6005 & 0.5002 & 0.7043 \\
\hline Rain bow(RA) & 0.9001 & 0.5677 & 0.765 & 0.4 \\
\hline Gast solar (GS) & 0.69 & 0.6894 & 1.6743 & 0.6213 \\
\hline Nifas silk (NS) & 0.798 & 0.8025 & 1.8425 & 0.8076 \\
\hline $\begin{array}{c}\text { Modern building } \\
\text { industry(MBI) }\end{array}$ & 0.599 & 0.4679 & 0.934 & 0.3066 \\
\hline
\end{tabular}

Table 2: Laboratory results of heavy metals analyzed from all sampling points.

from all effluent samples collected from paint manufacturing factories. So the value of $\mathrm{Cd}$ was above the permissible limit of Ethiopian standard $(0.2 \mathrm{mg} / \mathrm{l})$ and world health organization $(0.01 \mathrm{mg} / \mathrm{l})$. Therefore, there could be danger on the receiving environment. Similar, study reported in Mumbai, India largest contribution $(32.8 \mathrm{mg} / \mathrm{l})$ of Cd metal was due to the effluent from paint manufacturing industries.

Chromium (Cr): Chromium is generally more toxic at higher temperatures and its compounds are known to cause cancer in humans. Hexavalent chromium is highly unstable and powerful oxidizing agent that cause serious damage to health which causes lung and skin cancer. The experimental data showed that the mean $\mathrm{Cr}$ concentration in wastewater samples was detected in all sites (Table 2) which was very much higher than the permissible limit of $0.1 \mathrm{mg} / \mathrm{L}$ and 0.05 and $\mathrm{mg} / \mathrm{L}$ set by ES and WHO. The experimental data indicates that average chromium content in waste water samples was found to be minimum of $16.9 \mathrm{mg} / \mathrm{l}$ in effluent samples collected from dyes industries and maximum of $35.2 \mathrm{mg} / \mathrm{l}$ in effluent samples collected from paint industries so that paint manufacturing industries are the major source for release of toxic chromium metal in surrounding aquatic environment.

Lead $(\mathbf{P b})$ : In the present investigation, it was observed that the

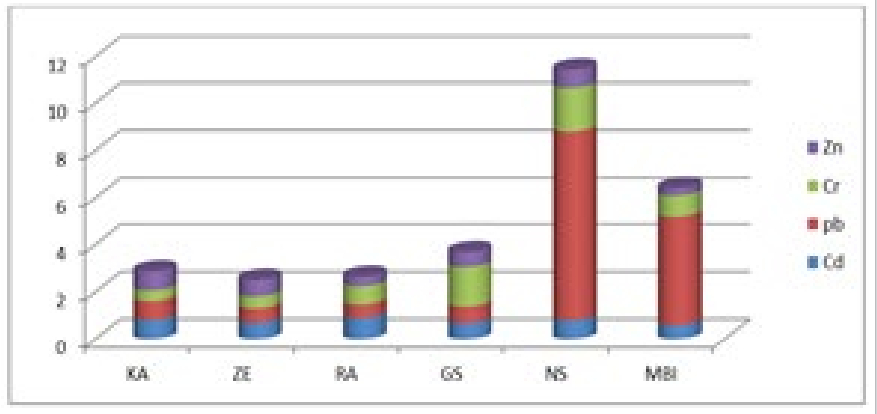

Figure 5: Concentration of heavy metals in paint industry effluent at different sites.

maximum concentration of $\mathrm{Pb}$ was $8.002 \mathrm{mg} / \mathrm{l}$ in effluent samples collected from NS paint manufacturing factories. Besides, the minimum concentration $(0.4679 \mathrm{mg} / \mathrm{l})$ of $\mathrm{Pb}$ was found in the effluent samples collected from paint factories meet Ethiopian standard (ES), but it did not meet the limit set that the range of the measured concentration of lead was $0.17-1.94 \mathrm{mg} / \mathrm{l}$ compared to the permissible value of WHO $0.01 \mathrm{mg} / \mathrm{l}[4,5]$.

Zinc (Zn): The mean concentration of $\mathrm{Zn}$ was recorded maximum $(0.8076 \mathrm{mg} / \mathrm{l})$ in waste water effluent samples collected from Nifas Silk (NS) paint manufacturing sites, while minimum mean concentration of $0.3066 \mathrm{mg} / \mathrm{L}$ was found in effluents collected from Modern building industry (MBI) paint factories. The results of the present investigation indicate that concentration of $\mathrm{Zn}$ in different industrial effluent samples sites was above the permissible limit of 5 and $15 \mathrm{mg} / \mathrm{L}$ as per ES and WHO reported that the range of values for zinc concentration in all the sampling points was between $0.3066-0.8076 \mathrm{mg} / \mathrm{l}$, lower than the maximum permissible value of as per ES and WHO mg/l (Figure 5).

\section{Conclusion}

From the results of the physico- chemical analyses, it is evident that all the analyzed parameters showed compliance with ES and WHO standards except pH in site Gast solar (GS); E.C in site Nifas silk (NS) and (Rain bow) RB; TSS in all sites Gast solar (GS), Kadisco (KA), Rainbow (RB), Zemilli (ZE) and Modern industry (MBI). However, TDS as per WHO in site Rainbow (RB), Gast solar (GS) and MBI beyond the limit. And also COD in site Rainbow (RB), Zemilli (ZE), Nifas silk (NS) and $\mathrm{MBI}$ are beyond the permissible limit set by ES $(250 \mathrm{mg} / \mathrm{l})$ and also GS beyond the permissible limit of WHO $(120 \mathrm{mg} / \mathrm{l})$. In view of the overall results obtained for heavy metals contents of the samples from the paint industry's environment, the paint industry effluent did seem to pose serious threat to the environment $[25,26]$.

\section{Acknowledgments}

We gratefully acknowledge the constructive comments and suggestions of anonymous reviewers.

\section{References}

1. Tesfay (2014) Peculiar health problems due to industrial wastes in Addis Ababa city. The case of akaki kality industrial zone.

2. Param (2007) Caramay. International Journal Environmental Research 1: 280 289.

3. Navneet Kumar DK, Sinha (2010) Drinking water quality management through correlation studies among various physicochemical parameters. A case study. International Journal of Environmental Sciences 1: 253-259.

4. Van Dyk JC, Pieterse GM, Van Vuren JHJ (2007) Histological changes in liver of Oreochromismossambicus (Cichlidae) after exposure to cadmium and zinc. Ecotoxocol Environ Safety 66: 432-440. 
Citation: Berihun D, Solomon Y (2017) Assessment of the Physicochemical and Heavy Metal Concentration from Effluents of Paint Industry in Addis Ababa, Ethiopia. Int J Waste Resour 7: 306. doi: 10.4172/2252-5211.1000306

Page 5 of 5

5. Dahunsi SO, Oranusi SU, Ishola RO (2012) Bioaccumulation pattern of cadmium and lead in the head capsule and body muscle of Clariasgariepinus exposed to paint emulsion effluent. Research Journal of Environmental and Earth Sciences 4: 166-170.

6. Enander RT, Cohen HJ, Gute DM, Brown LC, Desmaris AM, et al. (2008) Lead and methylene chloride exposures among automotive repair technicians. J Occup Environ Hyg 1: 119-125.

7. http://www.epa.gov/ttnatw01/hlthef/cadmium.html

8. Federal Democratic Republic of Ethiopia (2011) Ethiopia's climate-resilient green economy, Addis Ababa.

9. Hanawa T (2004) Metal ion release from metal implants. Mater Sci Eng C 24: 745-752.

10. Hazardous substances database (HSDB) (2006) Cadmium. National Library of Medicine Toxicology Data Network.

11. Lenntech BV (2012) Heavy metals.

12. Gupta V (2013) Mammalian faeces as bio-indicator of heavy metal contamination in Bikaner Zoological Garden, Rajasthan, India. Res J Animal Veterinary and Fishery Sci 1: 10-15.

13. Lokhande RS, Singare PU, Pimple DS (2011) Quantification study of toxic heavy metals pollutants in sediment samples collected from Kasardi river flowing along the Taloja industrial area of Mumbai, India. The New York Science Journal 4: 66-71.

14. National Toxicology Program (2004) Eleventh annual report on carcinogens. Research Triangle Park, National Toxicology Program.

15. Mannino DF, Holguin H, Mollie GG, Amanda Savage-Brown, Stock AL et al. (2004) Urinary cadmium levels predict lower lung function in current and former smokers: data from the Third National Health and Nutrition Examination Survey. Thorax 59: 194-198.
16. Manju (2015) Effects of heavy metals on human health. International Journal of Research.

17. Mishra S, Dwivedi SP, Dwivedi N, Singh RB (2009) Immune response and possible causes of $\mathrm{CD} 4^{+} \mathrm{T}$ - cell depletion in human immunodeficiency virus (HIV)-1 infection. Open Nutra J 2: 46-51.

18. Lippman M, Briant JK (1992) Particle transport through a hollow canine airway cast by high-frequency oscillatory ventilation. Experimental Lung Research 18 385-407.

19. Mohammed MA (2002) Industrial pollution and its impacts on little Akaki River.

20. Occupational Health and Safety Administration (2012) Chemical sampling information: Lead.

21. Occupational Health and Safety Administration (2012) Chemical sampling information: Cadmium.

22. Pandey Govind, Madhuri S, Shrivastav AB (2014) Fish cancer by environmental pollutants (1st edn.). Narendra Publishing House, Delhi, India.

23. Sahmoun AL, Case SA, Jackson G, Schwartz (2005) Cadmium and prostate cancer: A critical epidemiological analysis. Cancer Investigation 23: 256-263.

24. Schoof RA (2003) Guide for incorporating bioavailability adjustments into human health and ecological risk assessments part 1: Overview of metals bioavailability. Tri-Service Ecological Risk Assessment.

25. Santos EE, Lauria DC, Porto da Silveira CL (2004) Assessment of daily intake of trace elements due to consumption of foodstuffs by adult inhabitants of Rio de Janeiro city. Sci Total Environ 327: 69-79.

26. Jolly YN, Hossain A, Sattar A, Islam A (2012) Impact of heavy metals on water and soil environment of a paint industry. Journal of Bangladesh Chemical Society 25 : 159-165. 